\title{
NATURAL EMERGENCIES IN KYIV OBLAST
}

\author{
Lyudmyla BARANOVA \\ Taras Shevchenko National University of Kyiv, Ukraine \\ milab12@ukr.net
}

\begin{abstract}
The article discusses the main natural emergencies that occur in Kyiv oblast and lays down the classification of natural emergencies and hazards caused by anthropogenic influence. The author provides the analysis of natural hazards, revealing their negative impact and threat to the safety of the population, society, and environment, demonstrates the basic reasons for increasing the number of emergencies, and proposes some ways to reduce social and economic losses from natural emergencies.

Key words: threat, liquidation, emergencies, natural hazards, risk, disaster
\end{abstract}

UDC: 911.3

\section{НАДЗВИЧАЙНІ СИТУАЦІЇ ПРИРОДНОГО ХАРАКТЕРУ В КИЇВСЬКІЙ ОБЛАСТІ}

\section{Людмила БАРАНОВА}

Київський національний університет імені Тараса Шевченка, Україна

milab12@ukr.net

(C) Л. Баранова 
Анотація: У статті визначені основні загрози природного характеру на території Київської області. Подана класифікація надзвичайних ситуацій внаслідок небезпечних природних явищ, які спричинені техногенним впливом. Проведено аналіз небезпек природного походження, їхній негативний вплив та загрозу безпеці життєдіяльності населення, суспільству, навколишньому середовищу. Наведені основні причини збільшення кількості надзвичайних ситуацій. Запропоновані шляхи зниження соціально-економічних збитків від надзвичайних ситуацій природного характеру

Ключові слова: загроза, ліквідація, надзвичайні ситуації, природні небезпеки, ризик, стихійне лихо

$$
\text { Удк: } 911.3
$$

Вступ. Постановка проблеми. Сьогоднішня ситуація в Україні щодо небезпечних природних явищ, аварій i катастроф характеризується як складна. Стихійні явища, як правило, виникають у комплексі, що значно посилює їх негативний вплив. Тенденція зростання кількості надзвичайних ситуацій (НС), важкість їх наслідків змушують розглядати їх як серйозну загрозу безпеці кожної людини, суспільству та навколишньому середовищу, а також стабільності розвитку економіки країни. Сучасне життєве середовище містить багато джерел небезпек. Для того, щоб виникла реальна небезпечна ситуація, необхідна причина або умова, своєрідний «пусковий механізм», при йому потенційна небезпека переходить у реальну. Процесом розвитку небезпеки, реалізації потенційної загрози є тріада «джерело небезпеки - причина (умова) - небезпечна ситуація». Небезпечне природне явище - це подія природного походження або результат діяльності природних процесів, які за своєю інтенсивністю, масштабом поширення i тривалістю можуть вражати людей, об'єкти економіки та довкілля. Небезпечні природні явища, в основному, визначаються проявом трьох головних груп факторів - ендогенних, екзогенних та гідрометеорологічних процесів. Джерелом природної НС є небезпечне природне явище або процес, причиною виникнення якого може бути: землетрус, викид вулкану, обвал, сель, провал грунту, ерозія, перероблення берегів, цунамі, лавина, повінь, підтоплення, сильний вітер, смерч, пилова буря, суховій, сильні опади, засуха, заморозки, туман, гроза, природні пожежі, зміни складу і властивостей атмосфери, зміни стану гідросфери та біосфери тощо.

Аналіз останніх досліджень та публікацій. Дослідженням питань природно-техногенної безпеки в Україні протягом останніх років займаються провідні науковці, зокрема В. С. Бахаров, В. В. Бєгун, Б. М. Данилишин, С. І. Дорогунцов, Ю. С. Голіков, М. О. Клименко, О. Ю. Кононенко, А. Л. Мельничук, I. М. Науменко, А. М. Прищепа, О. М. Ральчук, А. В. Степаненко, О. В. Харламова, В. М. Шмандій [3, $4,5,6,7,11]$ та ін. Небезпечні та стихійні явища погоди на території України, загрози природного характеру та їх вплив на життєдіяльність людей, суспільства та навколишнього середовища розкриті в працях М. І. Адаменко, В. Н. Бабиченко, А. А. Григор'єва, К. Я. Кондрат'єва, М. Ю. Кулаковської, К. Т. Логвінова, С. В. Трача, Б. А. Шелудченка, І. А. Шелудченка [1, 2, 8, 10] та ін.

Формування цілей статті i постановка завдання. На території Київської області зберігається високий ризик виникнення надзвичайних ситуацій як техногенного так і природного характеру. Саме тому, метою даного дослідження є аналіз небезпек природного походження на території Київської області. Завданням роботи є визначення основних загроз природного походження та їхній вплив на життєдіяльність людини, суспільства та довкілля.

Виклад основного матеріалу. Останнім часом у науковий обіг увійшло нове поняття про ризик-як для окремої людини, так і для держави, і для всієї світової спільноти. Серед можливих ризиків розрізняють екологічні (природно-техногенні), соціальні, військові, етнографічні, транскордонні, побутові та інші. За ступенем всі вони можуть бути локальними, національними, регіональними та глобальними, а за ступенем впливу - надмірними (неприйнятними), гранично допустимими (максимально прийнятними) i прийнятними. Розрізняють також контрольовані та неконтрольовані ризики. Саме ризики є головним джерелом виникнення надзвичайних ситуацій, при яких на певній території порушуються сприятливі умови життя і діяльності людей, виникає загроза їх життю і здоров’ю, завдається шкода їх майну, а також господарству та навколишньому середовищу. Безпосередньою причиною виникнення ризиків можуть служити стихійні лиха, аварії, катастрофи, непродумана господарська діяльність, військові та етнічні конфлікти та ін. [6].

Надзвичайні ситуації природного характеру також викликані опосередковано і негативним техногенним впливом на оточуюче середовище, які в свою чергу поділяються на дві категорії: раптового (імпульсивного) та накопичуваного (кумулятивного) характерів.

До НС раптового (імпульсивного) характеру, що спровоковані техногенними причинами відносяться:

- зсуви, землетруси та інші небезпечні геологічні процеси;

- повені та інші небезпечні гідрологічні процеси;

- засухи та інші метеорологічні процеси;

- пожежі в лісах та на торфовищах;

- епідемії.

До НС природного походження, що спричинені техногенними чинниками i мають накопичуваний (кумулятивний) характер, а також регіональне та локальне розповсюдження відносяться:

- глобальні кліматичні зміни;

- виснаження грунтів;

- відсутність необхідної кількості природоохоронних територій;

- зменшення біорізноманіття. 
Більшість несприятливих та небезпечних явищ природи мають локальний або місцевий характер прояву, а деякі можуть досягати рівня національних, регіональних i також глобальних катастроф. Природні загрози Київської області визначаються фізико-географічними особливостями ㄲï території, яка розміщена на крайній півночі Українського Полісся. Клімат області помірно-континентальний, м'який 3 достатньою кількістю вологи. Виникнення надзвичайних ситуацій природного характеру значною мірою залежить від перебігу погодних умов, які на території Київської області мають значну мінливість. Загрози природного походження у Київській області представлені широким колом процесів і явищ геологічного, гідрометеорологічного і гідрологічного характеру, пожежами в екосистемах, інфекційними захворюваннями людей та соціальнонебезпечними хворобами.

Загрози геологічного характеру. В області спостерігаються такі геологічні процеси, як землетруси, зсуви, обвали, підтоплення, заболочування, просідання лесових порід тощо.

Сейсмічні станції України щороку реєструють десятки землетрусів 3 епіцентром в зоні Вранча (Румунія). У м. Києві та області максимально можливий ефект на грунтах II категоріїза сейсмічними властивостями не перевищує 6 балів (за 12-бальною шкалою MSK-64).

Ураженість території небезпечними екзогенними геологічними явищами становить 10,8 тис. км². 3суви $\epsilon$ одним iз найнебезпечніших i дуже поширених природних явищ. Поширення зсувів у Київській області-цеправийсхилр. Дніпротайогоправобережні притоки. Загальна площа зсувів 23,75 км², активних - 0,7700 км², у межах забудованих територій - 6,98 км². Загальна кількість зсувів у Київській області - 814, активних - 32, на забудованій території - 67, кількість об'єктів господарської діяльності у зоні зсувів - 9. У 2013 р. нові прояви активації зсувного процесу виявлені в с. Стайки Кагарлицького району (Канівське водосховище).

Небезпека зсувів полягає у тому, що величезні маси грунту, раптово зміщуючись, можуть призвести до руйнування будівель та споруд, залізничних i шосейних доріг, мостів та великих жертв серед населення.Масштабикатастрофизалежатьвідступеня забудови та заселення території, а також від величини самого зсуву. Для прогнозу і контролю розвитку зсувів проводять детальні геологічні дослідження і складають карти, із зазначенням зсувонебезпечних місць. Вартість робіт з попередження зсувів велика, проте матеріальний збиток у результаті зсуву та затрати на ліквідацію наслідків зсуву набагато перевищують комплекс запобіжних заходів, які включають систему моніторингу, оповіщення населення, плани організації робіт ліквідації наслідків та забезпечення життєдіяльності людей

Підтоплення охоплює 10,8 тис. км², або 16,0 \% території області. Із 16759 км² сільськогосподарських угідь в Київській області заболочено 833 км²,

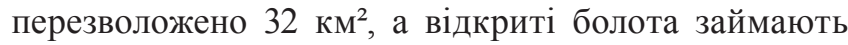
площу 496 км².
Просідання лесових грунтів спостерігається на території 10207, 5 км² (I типу) і 392,5 км² (II типу).

Переробка берегів водосховищ має ті самі чинники та умови розвитку, що й абразія. Створення водосховищ порушує природний хід формування схилів річкових долин на зміну річковій ерозії приходить хвильова абразія. Інтенсивність переробки берегів залежить від розмірів водосховищ, яке визначає параметри хвиль та геологічної будови. Переробка берегів водосховищ Дніпровського каскаду відмічається:

а) на Київському водосховищі довжина ділянки переробки складає 50 км, швидкість переробки берегової лінії становить 8-10 м/рік. На ділянці довжиною 10 км у межах Київської області (сс. Старі та Нові Петрівці - Вишгород), де в останні роки відмічається незначна активація, схили розмиваються зі швидкістю 0,1 м/рік;

б) на Канівському водосховищі (у межах Київської області) довжина ділянки переробки складає 75 км, на ділянці сучасної активації (сс. Халеп’є Гребені - Стайки - Ходорів), де висота абразійного уступу становить 0,6-6,0 м, а кути нахилу схилів 30-60 , інтенсивність переробки берегового уступу незначна і відбувається рівномірно зі швидкістю 0,1$0,8 \mathrm{м} /$ рік.

Загрози у природних екосистемах. Значну територію області займають ліси і торфовища, на яких можливі пожежі. Проблема збереження лісів від вогню в останні роки набула особливої гостроти у зв'язку 3 підвищенням температури повітря, зменшенням кількості опадів та сильними вітрами. Лісові пожежі є одним з найбільш непередбачуваних та руйнівних лих, навіть якщо вдається зупинити ïx розповсюдження. Окрім небезпеки, яку несе у собі вогонь, суттєвою проблемою, що супроводжує будь-яку пожежу, є задимлення. Найбільша кількість пожеж фіксується у липні-серпні, де очікується посушлива вітряна погода 3 невеликою кількістю опадів, що сприяє виникненню осередків пожеж у природних екосистемах. Загальна площа зони можливих пожеж у Київській області становить 1141,0 тис. га, у тому числі лісових пожеж - 548,0 тис. га (або 85,5 \% площі лісів), з них переважно 371,0 тис. га сильних верхових та низових і 177,0 тис. га слабких низових. Площа ймовірних польових пожеж в області становить 593,0 тис. га або дорівнює 35,5\% від площі сільськогосподарських угідь. Загальний коефіцієнт пожежної небезпеки по території області становить $1,8 \cdot 10^{-1}$. Для області характерно виникнення природних пожеж у пожежонебезпечний період в господарствах АПК, прилеглих до лісових масивів Баришівського, Бориспільського, КиєвоСвятошинського, Іванківського, Вишгородського, Броварського, Обухівського та Богуславського районах. Також існує проблема загоряння торф'яників 3 реальною загрозою сільським населеним пунктам. Найчастіше вони виникають наприкінці літа в місцях видобування торфу через необережне поводження 3 вогнем, відрозрядублискавкиабосамозаймання. Торф горить повільно на всю глибину його залягання, тому виникають значні труднощі при його гасінні, бо такі 
пожежі охоплюють ще й великі території. Організація їх гасіння передбачає залучення значних коштів, матеріальних резервів, використання тривалого часу сил та засобів. Торф'яних пожеж упродовж 2013 р. у Київській області було зафіксовано 11 [13].

Загрози гідрометеорологічного характеру. Атмосферні процеси над територією області обумовлюють часту повторюваність таких несприятливих метеорологічних явищ, як сильний дощ, сильний вітер, заморозки, сильна ожеледиця на електролініях та автодорогах, ожеледиця.

За повторюваністю, площею поширення i середньорічними матеріальними збитками повені займають перше місце серед стихійних лих гідрометеорологічного характеру. Особливістю повеней, як i деяких інших небезпек природного характеру ,є те, що їх неможливо уникнути. Проте, повені відрізняються від інших стихійних лих тим, що деякою мірою прогнозуються. Прогнозувати ймовірність повені набагато легше, ніж передбачити момент ii початку. Точність прогнозу зростає при отриманні надійної інформації про кількість та інтенсивність опадів, рівні води в річці, запаси води в сніговому покрові, зміни температури повітря, довгострокові прогнози погоди тощо.

Для даного регіону характерне часткове підтоплення житлових, промислових будівель і сільгоспугідь, у басейні річок Дніпро та Десна в період весняних повеней (всього 113 населених пунктів в 21 районі). Максимальні рівні були вищими за середні багаторічні показники на річках Київщини (Уж, Тетерів).

Вирішити проблему повеней можна завдяки зниженню їх негативних наслідків, приймаючи організаційно-управлінські рішення. Досить важливий шлях регулювання стоку й запобігання повеней - ландшафтно-меліоративні заходи.

Для Київської області також властиві посушливі умови та явища. Значна частка в загальному сільськогосподарському виробництві України належить Київській області 3 їі величезними посівними площами зернових, технічних, овочевих та плодово-ягідних культур. Суховї найбільшу шкоду завдають сільськогосподарському виробництву, що позначається на життєдіяльності рослин, порушуючи їх водний баланс у фазі розвитку, що в свою чергу призводить до зменшення урожаю, а інколи i до втрати його.

Кількість днів із суховіями за теплий період збільшилась, особливо впродовж останніх років i відповідно зросла сума їх за рік. Середня місячна кількість днів із суховієм по регіону змінюється від 1 до 8. Максимальна кількість днів із суховієм за теплий період спостерігається у серпні, частота ix виникнення низька у квітні та вересні-жовтні, місцями збільшується у травні-червні. За останні три десятиліття максимальна кількість днів з суховіями в Київській області, внаслідок антициклону, відмічалася у 2010 р. і становила 33 дні [9]. Багаторічна динаміка кількості днів із повторюваністю суховієм протягом останніх десятиліть у Київському регіоні характеризується загальною тенденцією доїх стійкого збільшення, внаслідок зміни в умовах сучасного клімату, що призводить до серйозних порушень у біоценозах та завдає великих матеріальних збитків сільськогосподарському виробництву.

У Київській області спостерігається ожеледь, яка утворюється виключно при випаданні переохолоджених опадів при від'ємній температурі повітря. Головна небезпека ожеледі в швидкому «намерзання» льоду на проводах, гілках дерев, тросах і т.д. При цьому намерзанні «висячі» крижини можуть швидко досягати великої товщини, під дією яких обриваються електролінії, ламаються гілки на деревах та ін. Збереження відкладень ожеледі може тривати кілька діб. Сильна ожеледиця на автодорогах в області спостерігається взимку та восени, коли після періоду відлиги або дощу настає період похолодання, а також внаслідок замерзання мокрого снігу, крапель дощу або мряки, при коливаннях температури близько нуля градусів. Збереження утвореної ожеледиці може тривати багато днів поспіль, поки не буде вона покрита зверху сніговим покривом або не зруйнується повністю у результаті інтенсивного підвищення температури повітря і грунту. Ожеледь та ожеледиця спостерігаються одночасно, бо їм потрібні приблизно однакові погодні умови, які завдають велику шкоду господарству, населенню, ожеледиця на дорогах заважає рухові транспорту, створює ризик виникнення аварій.

Характерні для Київської області і сильні опади у вигляді дощу та снігу. Наприкінці березня 2013 р. Україну, а також і область накрив сніговий шторм, який прийшов 3 Балкан. Протягом доби випало 50 міліметрів опадів (при місячній нормі 47 міліметрів), що становить півметра снігового покриву. У зв'язку з ускладненням погодних умов було оголошено надзвичайний стан. Аномальний снігопад паралізував залізничний та авіаційний рух, спричинив затори на дорогах, люди залишали свої авто на узбіччі та йшли пішки. В області від негоди були знеструмлені 36 населених пунктів. До робіт 3 відновлення електропостачання населених пунктів були залучені аварійні бригади обленерго. Рясні дощі у вересні 2013 р. побили рекорд, який не спостерігався в України протягом 90 років, випала 4-місячна норма опадів.

Небезпечні інфекиійні захворювання людей. В умовах зростаючого антропогенного впливу на навколишнє середовище, збільшення резистентності збудників інфекційних захворювань до хіміотерапевтичних та дезінфекційних засобів, різноманітності природних зон та біоценозів території України, що створюють сприятливі умови для довготривалого існування природно-вогнищевих інфекцій, таких як, туляремія, лептоспіроз, сибірська виразка, правець, кліщовий енцефаліт та багато інших хвороб, виявлення нових нозологічних форм, що раніше не зустрічалися на території держави, підвищення міграції населення, росту масштабів міжнародної торгівлі продуктами харчування, а також стихійних лих та катастроф з'явились об’єктивні передумови для швидких змін епідемічної ситуації на окремих територіях [13]. 
У Київській області площа епідемічно та епізоотично небезпечних інфекційних захворювань людей за ризиком зараження I, II та III ступенів території становить:

- аскаридозом - 28,90 тис. км² 3 населенням 4331,2 тис. осіб;

- правцем - 22,00 тис. км² 3 населенням 1390,3 тис. осіб;

- лептоспірозом - 15,00 тис. км² 3 населенням 2141,5 тис. осіб;

- туляремією - 6,00 тис. км² 3 населенням 865,5 тис. осіб;

- сибірською виразкою-0,30 тис. км² 3 населенням 4,43 тис. осіб.

Наприклад, у 2014 р. в Київській області було зафіксовано 11 випадків захворювань людей на лептоспіроз (Києво-Святошинський район - 3, Баришівський, Білоцерківський, Васильківський, Іванівський, Миронівський, Таращанський, Фастівський, Яготинський - по 1 випадку).

Захворюваність на соціально-небезпечніхвороби. Найбільш серйозною проблемою, яка загрожує національній безпеці України залишається стан захворюваності на особливо соціально-небезпечні хвороби туберкульоз та ВІЛ-інфекцію. Епідемічну ситуацію із захворюваності на туберкульоз в України, яка була зареєстрована в 1993 році, а також і в області, слід розглядати як надзвичайну. На жаль, епідемія і досі невпинно розповсюджується. В 90-і роки захворюваність на всі форми туберкульозу зросла майже вдвічі. У 2005 р. кількість хворих на активний туберкульоз з діагнозом, що встановлений уперше в житті, становила 1244 особи (70,4 осіб на 100 тис. населення) і була найвищою за всі роки спостереження. Партнерська програма ВOO3 «Зупинити туберкульоз» (Stop TB Partnership) визначилацьогорічну тему Всесвітнього дня боротьби з туберкульозом як «Охопити три мільйони: знайти, лікувати, вилікувати кожного», яке відзначається 24 березня кожного року.

Київська обласна організація Товариства Червоного хреста України, яка сприяє країні у боротьбі 3 туберкульозом, здійснює різні національні, регіональні програми, які направлені на зменшення захворюваності та смертності населення від туберкульозу. В 23 районах Київської області реалізується проект «Медико-соціальний супровід та формування прихильності до лікування туберкульозу» за підтримки Глобального Фонду. Проектом передбачено щоденний контроль прийому ліків хворими $з$ числа вразливих верств населення, ознайомлення 3 формами та методами сучасного лікування та необхідності дотримуватися норм санітарії щодо запобігання захворювання на туберкульоз, ведеться пропаганда здорового способу життя, а також надається психологічна підтримка, забезпечення продуктовими наборами. Станом на перший квартал 2013 р. в області охоплено медикосоціальним супроводом - 343 хворих, 3 них - 230 чоловік закінчили лікування від туберкульозу. Було видано 1293 продуктових наборів на суму - 133 409,04 грн. Серед населення проводиться роз'яснювальна робота з питань профілактики цього захворювання [12].

У Київській області проводиться також профілактика інфікування ВІЛ серед наркозалежних та їх найближчого оточення. Діяльність реалізується за фінансової підтримки МБФ «Міжнародний Альянс з ВІЛ/СНІД в Україні». В рамках діяльності в м. Біла Церква, м. Бориспіль, м. Боярка, м. Бровари, м. Васильків та смт. Глеваха працюють консультаційний та вуличні пункти, які надають такі послуги:

- консультаціїз питань ВІЛ/ СНІДу, туберкульозу, гепатитів та інших небезпечних хвороб;

- направлення в програми реабілітації, детоксикації, догляду та підтримки ВІЛ-позитивних;

- ранне виявлення туберкульозу: скринінгопитування, направлення на діагностику та лікування;

- тестування експрес-тестами на ВIЛ та гепатит $\mathrm{C}$;

- консультації психолога;

- сприяння у постановці на замісну підтримувальну терапію;

- надання засобів особистої безпеки;

- соціальний супровід людей, які живуть з ВІЛ інфікованими;

- інформаційні заняття щодо працевлаштування та законних прав.

Кількість офіційно зареєстрованих ВІЛінфікованих у 2005 р. по області становила 333 особи (18,9 осіб на 100 тис. населення), а хворих на СНІД 95 осіб, що характеризується постійним зростанням [14].

За інтегральним показником небезпеки, згідно 3 розрахунками МНС України, Київська область належить до регіонів помірної небезпеки $(0,248)$, що є близьким до середньоукраїнського показника - 0,227. Динаміка НС природного характеру у Київській області за період 2004-2013 рр. наведена в таблиці 1.

У 2008 році в області було зафіксовано максимальну кількість - 6 НС природного характеру, які спричинили такі види ускладнень в роботі галузей господарства та життєдіяльності населення: підтоплення талими водами та внаслідок злив, пожежі в природних екологічних системах, знеструмлення населених пунктів через посилення вітру, сильні опади, налипання мокрого снігу, загибель людей на воді. Найменша кількість НС природного характеру в області було зафіксовано у 2011 р. - 1, 2005 та 2013 pp. - 2. 2013 рік запам'ятався великим снігопадом наприкінці березня та зливами у вересні.

Основні причини збільшення кількості $\mathrm{HC}$, як наслідок, зниження рівня природно-техногенної безпеки (ПТБ) мають свої особливості для кожного виду НС, проте їх можна об'єднати в окремі групи: природні, організаційні, технічні.

До природних причин, що істотно знижують рівень ПТБ, можна віднести постійне зростання антропогенного впливу на навколишне природне середовище, високу урбанізацію територій, розміщення об'єктів господарської діяльності та населених пунктів у зонах потенційної небезпеки, 
Таблиия 1

Кількість надзвичайних ситуацій (НС) в Київській області за період 2004-2013 роки

\begin{tabular}{|l|c|c|c|c|c|c|c|c|c|c|}
\hline & \multicolumn{10}{|c|}{ Роки } \\
\hline Показники & 2004 & 2005 & 2006 & 2007 & 2008 & 2009 & 2010 & 2011 & 2012 & 2013 \\
\hline $\begin{array}{l}\text { К-сть НС } \\
\text { загалом }\end{array}$ & 11 & 16 & 13 & 17 & 15 & 12 & 9 & 7 & 13 & 4 \\
\hline $\begin{array}{l}\text { НС природного } \\
\text { характеру }\end{array}$ & 3 & 2 & 4 & 5 & 6 & 4 & 5 & 1 & 4 & 2 \\
\hline
\end{tabular}

аномальні зміни деяких параметрів атмосфери, гідросфери та літосфери.

Організаційними причинами $є$ низька достовірність прогнозування небезпечних природних явищ; згортання заходів щодо запобігання деяким небезпечним природним явищам, зокрема паводкам; нерозвиненість чи відсутність систем моніторингу компонентів природного середовища; низька технологічна дисципліна на виробництвах, особливо екологічно небезпечних, ігнорування вимог екологічних, санітарно-гігієнічних норм та стандартів у промисловості, будівництві, комунальному господарстві, транспорті й інших галузях.

Технічними причинами, що призводять до $\mathrm{HC}$, можна вважати відсутність чи критичний стан гідротехнічних, протизсувних, протиселевих та інших захисних споруд; недотримання або порушення технології виробництва при значній фізичній зношеності більшості основних виробничих фондів підприємств України.

Висновки і перспективи подальших розвідок.

Знання причин виникнення, динаміки розвитку та характеру вражаючих факторів природних надзвичайних ситуацій дозволяє зменшити загрозу життю і здоров'ю людей, запобігти або зменшити матеріальні та економічні збитки у господарській діяльності, ефективно проводити комплекс попереджувальних, рятувальних та аварійних робіт, пов'язаних 3 надзвичайними природними ситуаціями. До роботи в районі надзвичайної ситуації природного характеру залучається значна кількість людських, матеріальних і технічних ресурсів. Запобігання надзвичайним ситуаціям, ліквідація їх наслідків, максимальне зниження масштабів втрат та збитків, зниження ризиків НС різного походження перетворилося на загальнодержавну проблему і $\epsilon$ одним 3 найважливіших завдань органів виконавчої влади і управління всіх рівнів. Це вимагає проведення комплексного аналізу загроз, здійснення їхнього постійного моніторингу і розробки на цій основі обгрунтованих запобіжних заходів, спрямованих на відвернення тих загроз, реалізація яких може призвести до значних негативних наслідків.

Зниження соціально-економічних втрат від надзвичайних ситуацій природного походження можна досягти шляхом:

- підвищення стійкості промислових, транспортних i житлово-комунальних об'єктів до негативного впливу стихійних явищ;

- удосконалення системи моніторингу геологічного середовища, в першу чергу територій, уражених підтопленням, зсувом і та ін.;

- вдосконалення системи гідрометеорологічних спостережень;

- систематичного проведення просвітницької роботи серед населення 3 питань дотримання санітарно-гігієнічних вимог, профілактики та захисту від інфекційних захворювань;

- підвищення рівня обізнаності населення про ризики можливих природних НС та заходи щодо їх зниження.

Зниження рівня ризику, в свою чергу, приведе до скорочення кількості надзвичайних ситуацій, а також постраждалих, загиблих, обсягів матеріальних збитків, а також скоротиться площа зон можливого ураження при виникненні НС природного характеру.

\section{References:}

1. Adamenko M. Ì. Prirodnì zagrozi ta harakter ïh proâvu ì dï na lûdej, tvarin, roslin, ob'êkti ekonomiki [Natural hazards, their nature and impact on people, animals, plants, objects of economy]. Kharkiv, 2012, 29 pp. (In Ukrainian).

2. Babičenko V. N. Stihijnye meteorologičeskie âvleniâ na Ukraine i v Moldovii [Natural disastrous weather events in Ukraine and Moldova]. Leningrad, 1991, 224 p. (In Russian).

3. Bêgun V. V., Naumenko İ. M. Bezpeka žittêdiâl'nostì (zabezpečennâ social'noï, tehnogennoï ta prirodnoï bezpeki: Navčal'nij posibnik [Emergency management (social, technological and natural security: Handbook]. Kyiv, 2004, 328 p. (In Ukrainian).

4. Danilišin B. M., Stepanenko A. V., Ral'čuk O. M. Bezpeka regìniv Ukrä̈ni i strategiâ ï garantuvannâ [Regions of Ukraine: safety and the strategy of its assurance]. Monograph in 2 volumes, Kyiv, 2008.- Vol. 1 Prirodnotehnogenna (ekologična) bezpeka [Natural and man-made (environmental) security]. - 389 c. (In Ukrainian).

5. Doroguncov S. İ., Ral'čuk O. M. Upravlìnnâ tehnogenno-ekologičnổ bezpekô̂ u paradigmì stalogo rozvitku [Management of technogenic-ecological safety under the paradigm of sustainable development]. Kyiv, 2001, 174 p. (In Ukrainian). 
6. Gaponenko A. V. Zagal'na ekologiâ. Lekciâ dlâ studentìv I kursu [General ecology. Lecture for $1^{\text {st }}$ course students], 2006. (In Ukrainian).

7. Grigor'ev A. A., Kondrat'ev K. Â. Prirodnye i antropogennye èkologičeskie katastrofy. Klassifikaciâ i osnovnye harakteristiki [Natural and anthropogenic environmental disasters. Classification and main characteristics]. Issledovaniâ Zemli iz kosmosa [Spacecraft Earth Studies], 2000, No. 2, pp. 72-83. (In Russian).

8. Logvinov K. T. Babičenko V. N., Kulakovskaâ M. Û. Opasnye âvleniâ pogody na Ukraine [Dangerous weather phenomena in Ukraine]. Trudy UkrNDGMI [Works of Ukrainian Hydrometeorological Institute], 1972, Vol. 110, 236 pp. (In Russian).

9. Pisarenko L. A. Mìžrìčna dinamìka ta povtorûvanìst' suhoviïv na teritoriï Kï̈vs'koï oblastì [Interannual dynamics and the frequency of droughts in Kyiv oblast]. Časopis kartografiï [Journal of Cartography], 2014, pp. 139147. (In Ukrainian).

10. Šeludčenko B. A. Trač S. V., Šeludčenko İ. A. et al. Nadzvičajnì situacï prirodnogo ta antropogennogo harakteru [Natural and man-made emergencies]. Kamianets-Podilskyi, 2010, 150 p. (In Ukrainian).

11. Šmandij V. M., Klimenko M. O., Golik Û. S., Priŝepa A. M., Baharov V. S., Harlamova O. V. Ekologična bezpeka: pidručnik [Environmental security: Handbook]. Kherson, 2013, 366 p. (In Ukrainian).

12. The Ministry of Health of Ukraine (official web-site). Access mode: http://www.moz.gov.ua.

13. The State Emergency Service of Ukraine (official web-site). Access mode: http://www.mns.gov.ua.

14. The website on countering HIVIAIDS and other socially dangerous diseases. Access mode: (http://dssz.gov. ua). 